DOI: $10.7819 /$ rbgn.v15i48.1351

Subject Area: Accounting and Controlling

\title{
To Sir with Love: the relations between teacher qualification and student performance in Accounting
}

\author{
Ao Mestre com Carinho: relações entre as qualificações docentes e 0 \\ desempenho discente em Contabilidade
}

\section{Al Máster con Cariño: relación entre la cualificación de los docentes y el rendimiento de los estudiantes en Contabilidad}

\author{
Gilberto José Miranda ${ }^{1}$ \\ Silvia Pereira de Castro Casa Nova ${ }^{2}$ \\ Edgard Bruno Cornacchione $\mathrm{Jr}^{3}$
}

Received on June 25, 2012 / Approved on September 3, 2013

Responsible Editor: Ivam Ricardo Peleias, Dr.

Evaluation Process: Double Blind Review

\section{ABSTRACT}

Accounting scholars who discuss the teaching of Accounting highlight two fundamental types of qualification for teaching staff in Accountancy programs: academic qualification (AQ), which refers to the teacher's preparation for research; and professional qualification (PQ), defined by the teacher's connection with current professional practices in the job market. Educational literature on higher education teaching, in turn, appoints a third type: pedagogical qualification $(\mathrm{PeQ})$, which relates to the systemized preparation for teaching practice in the university context. Considering
\end{abstract}

undergraduate Accountancy students' low performance levels in the National Exam for the Assessment of Student Performance (Exame Nacional do Desempenho dos Estudantes/ Enade), this research aimed to investigate the relations between student performance and teacher qualification. To identify variables related to teaching staff qualification, a questionnaire was developed, validated and applied in 218 higher education institutions (HEIs) that offer undergraduate Accountancy programs. These variables were compared with graduates' performance at the same institutions, verified on ENADE's basis, using linear regression and

1. Doctor in Controlling and Accounting by University of São Paulo. Professor at Uberlândia Federal University (UFU). [gilbertojm@facic.ufu.br]

Author' address: Av. João Naves de Avila, 2.121 - Bloco F - Sala 1F219 - Campus Santa Mônica - Uberlândia - MG CEP 38.400-902 - Brasil

2. Doctor in Controlling and Accounting by University of São Paulo. Professor at São Paulo University. [silvianova@usp.br]

3. PhD in Human Resource Education by University of Illinois - System, USA. Professor at University of São Paulo. [edgardbc@usp.br]

Authors' address: Av. Prof. Luciano Gualberto, 908 - Cidade Universitária, Sao Paulo - SP CEP 05508-900, Brasil 
correlation analysis. The results partially confirm the established hypotheses: only academic qualification shows a significant regression coefficient at $5 \%(\mathrm{p}$-value $=0.000)$ and a significant positive correlation at $1 \%$. Professional and pedagogical qualification showed no significant correlations. The AQ rate at public HEIs is also significantly higher than at private HEIs.

Keywords: Accounting. Teacher qualification. Student performance. National Exam for the Assessment of Student Performance - ENADE. Brazil.

\section{RESUMO}

Os estudiosos da área contábil, que discutem o ensino da Contabilidade, apontam dois tipos de qualificação essenciais ao quadro docente de um curso de Ciências Contábeis: a qualificação acadêmica (Qac), que se refere à preparaçáo do docente para a pesquisa, e a qualificação profissional (Qpr), caracterizada pela ligação que o docente mantém com as práticas profissionais vigentes no mercado de trabalho. A literatura da área educacional que discute o ensino na universidade, por sua vez, aponta uma terceira: a qualificação pedagógica (Qpe), que diz respeito à preparação sistematizada para o exercício da docência no ambiente universitário. Em razão do baixo desempenho dos discentes dos cursos de graduação em Ciências Contábeis no Exame Nacional de Desempenho de Estudantes (Enade), esta pesquisa teve como propósito investigar as relaçóes existentes entre o desempenho discente e a qualificação docente. Como forma de identificar variáveis concernentes à qualificação do corpo docente, foi desenvolvido e validado um questionário, aplicado a 218 instituiçôes de ensino superior (IES) que ofertam cursos de graduação em Contabilidade. Essas variáveis foram confrontadas com o desempenho dos alunos concluintes por instituição, apurado com base no Enade, utilizando regressão linear e análise de correlação. Os resultados apurados mostram que os cursos que apresentam as maiores notas na avaliação Enade são aqueles que possuem também os maiores níveis de qualificação acadêmica (professores titulados, pesquisas e publicaçôes). Esses resultados sugerem que o investimento por parte do governo e das próprias IES na oferta de programas de pós-graduação stricto sensu poderá elevar o nível de desempenho discente em Ciências Contábeis.

Palavras-chave: Contabilidade. Qualificação docente. Desempenho discente. Exame Nacional de Desempenho de Estudantes - Enade. Brasil.

\section{RESUMEN}

Los estudiosos del área contable que debaten sobre la enseñanza de la Contabilidad, muestran dos tipos de habilidades esenciales para el sector docente de un curso de Ciencias Contables: la cualificación académica (Qac), que se refiere a la preparación del docente para la investigación y la cualificación profesional (Qpr), que se caracteriza por la conexión que el docente tiene con las actuales prácticas profesionales en el mercado laboral. La literatura sobre la educación que analiza la enseñanza en la universidad, a su vez, apunta una tercera: la cualificación didáctica (Qpe), que se refiere a la preparación sistemática para la práctica de la enseñanza en el ámbito universitario. Teniendo en cuenta este marco teórico y el bajo rendimiento de los estudiantes de los cursos de graduación en Contabilidad en el Examen Nacional de Desempeño de Estudiantes (ENADE), este estudio tuvo como propósito investigar la relación entre el rendimiento de los estudiantes y la cualificación de los docentes. Con el fin de identificar las variables relativas a la cualificación del cuerpo docente se desarrolló, validó y aplicó un cuestionario a 218 instituciones de educación superior (IES) que ofrecen cursos de Graduación en Ciencias Contables. Estas variables fueron comparadas con el desempeño de los estudiantes concluyentes por institución, calculado sobre la base del ENADE utilizando regresión lineal y análisis de correlación. Los resultados obtenidos confirman, en parte, las hipótesis establecidas: sólo los títulos académicos presentaron un coeficiente de regresión significativa del 5\% (p-valor $=0,000)$ y correlación positiva y significativa del $1 \%$.

Palabras clave: Contabilidad. Cualificación del profesor. Rendimiento de los alumnos. Examen Nacional de Desempeño de Estudiantes ENADE. Brasil. 


\section{INTRODUCTION}

Brazilian Accounting has undergone major changes, first of all based on the expansion of higher education and graduation. According to data from the National Higher Education Census (Censo Nacional de Educação Superior - Instituto Nacional de Estudos e Pesquisas Educacionais Anísio Teixeira/INEP, 2010), the undergraduate program in Accounting is the sixth in enrollment (classroom and distance) in Brazil. Over 235,000 students are enrolled, taking up $4 \%$ of all vacancies in higher education. Likewise, stricto sensu postgraduate studies in Accounting have expanded significantly since 1998, when there were only three master's degree programs and one doctorate program. Currently, in Brazil, there are nineteen postgraduate stricto sensu programs, including four doctorate courses, four professional master's degrees and seventeen master's degrees authorized by the Coordination for Improvement of Higher Education Personnel (Coordenação de Aperfeiçoamento de Pessoal de Nível Superior/Capes).

As a result of this expansion, over the last few years there has been greater emphasis on research about Accounting and the profession has been more valued, two facts that have been made evident in various ways, including the following:

a) major conferences such as the USP Congress of Controllership and Accounting (Congresso USP de Controladoria e Contabilidade), in 2001, and the ANPCONT Congress (Congresso ANPCONT), in 2007, as well as several other smaller scientific meetings;

b) an increase in the amount of scientific journals - most current journals, and that have been assessed by CAPES, belong to this period;

c) implementation of Law No. 12.249, in 2010 (BRAZIL, 2010), making exams of sufficiency mandatory for bachelors in Accounting before registering in Regional Accountancy Boards (results of the first exam, carried out in 2011, offer a worrying result: only $30 \%$ of Accounting graduates and $24 \%$ of Accounting technicians, all over Brazil, were approved). This Law also marks the gradual withdrawal of accounting technicians from the market, since it makes being Bachelor of Accounting Sciences mandatory to the profession, from 2015 on;

d) the Federal Accounting Council (Conselho Federal de Contabilidade/CFC), based on Decree No. 5.773 of May 9, 2006 (BRAZIL, 2006), begins a partnership with the Ministry of Education to monitor the quality of Accounting courses in Brazil. In this partnership, the CFC, which best knows the technical aspects of the profession, participates in courses' authorization and recognition processes.

Furthermore, the expansion of supply, with the expected democratization of access, provided, a little later on, reflection about the quality of higher education in the field, opening space for debate, research and structuring of actions. So as to meet this demand, more professors are necessary, and their qualification is an essential aspect. Thus, professor qualification examination and understanding of their impact on student performance gain relevance.

Accordingly, three dimensions can be found in literature, scattered amongst different researchers: Academic Qualification (Qac), referring to teacher preparation as to the research concerning topics that he teaches (ANNISETTE, KIRKHAM, 2007; CUNNINGHAM, 2008; FRANCO, 2009; LIBÂNEO, 2009; NJOKU, HEIJDEN, INANGA, 2010; PIERRE et al., 2009; RUFF, THIBODEAU, BERDARD, 2009; SEVERINO, 2009); Professional Qualification (Qpr), indicating the professor's connection with current accounting practices in the professional field (ANNISETTE, KIRKHAM, 2007; GEARY, KUTCHER, PORCO, 2010 ; HARMER, 2009; MARSHALL et al., 2010; MILEY, 2009; NJOKU, HEIJDEN, INANGA, 2010; TRAPNELL et al., 2009; VASCONCELOS, 2009; VOLPATO, 2009); and Teaching Qualification (Qpe): the systematic preparation for the teaching profession, referring to the full capacity of teaching, Accounting teaching methods, policies and programs in support of continuous training of professors maintained by Higher Education Institutions or the Accounting 
Sciences course (ALMEIDA, PIMENTA, 2009; ANDERE, ARAÚJO, 2008; EZCURRA, 2007; FRECKA, RECKERS, 2010; MARSHALL et al., 2010; MIRANDA, 2010; SEVERINO, 2009; SHULMAN, 1986, 2005; SLOMSKI, 2009).

A complex scenario for the teaching profession in Accounting can be seen ahead, amplified by the adoption of international standards, by the results of the first sufficiency exam, held in 2011, and by the results of the latest National Exam for the Assessment of Student Performance (Exame Nacional de Desempenho de Estudantes/Enade) carried out in 2009, in which only $16.6 \%$ of the Higher Education Institutions scored 4 and 5. In this context, this paper aims to examine the effect of teacher qualification on student performance through the following research question: what is the relationship between student performance and teacher qualification in undergraduate Brazilian Accounting courses?

The result of the grades of students who graduated from Enade in 2009 will be used as proxy for student performance (ANDRADE, 2011). To calculate teaching qualification, we will consider variables referring to each of the qualifications in literature, mentioned above, and confirmed by a panel of experts.

The very context of the expansion of higher education and postgraduate studies in Accounting are relevant justifications for an investigation to identify which teaching qualifications are related to Accounting students' achievements. Furthermore, this paper may contribute to the training of future teachers, as well as to the preparation of current teachers in this period of consolidation of international Accounting standards in Brazil.

This article is organized as follows: following this brief introduction, we present a theoretical review of teaching qualification in Accounting; next we describe the research method and discuss its limitations; and results are analyzed in view of the established question, and is followed by concluding remarks.

\section{THEORETICAL FRAMEWORK}

\section{I Teaching qualifications in Accounting}

Until very recently, teaching in higher education, in general, was not the object of research by teachers and researchers. It was assumed, on one hand, that having specific knowledge in the area that was being taught was enough for becoming a teacher - and, on the other hand, that since higher education students are adults, they are be able to learn without a teacher with any didactic or pedagogical training. This way of thinking, however, has been much criticized. In the contemporary world, Education scholars ended up noticing this gap in the training in higher education teachers (PIMENTA, ANASTASIOU, 2002; SEVERINO, 2009; SHULMAN, 1986, 2005), namely, the need for pedagogical qualification for higher education teaching.

With regard to teachers of bachelor courses, concern is even greater, because, apart from not undergoing any kind of pedagogical training during graduation (in disciplines offered in undergraduate teaching), these professionals also have other challenges related to didactic teaching, as Shulman explains:

Pedagogies that provide the bridge between theory and practice are never simple. They include highly complex performances involving observation and analysis, reading and comprehension, questions and answers, conjectures and refutations, questions and answers, problem and hypothesis, question and evidence, individual intervention and collective deliberation. (SHULMAN, 2005, p. 56).

Recently, many Accounting scholars have observed, in Brazil, the importance of knowledge in the didactic and pedagogical training of teachers who are outstanding amongst students (CATAPAN, COLAUTO; SILLAS, 2012; GRADVOHL, LOPES, COSTA, 2009; MIRANDA, CASA NOVA, CORNACHIONE, 2012; NOGUEIRA, CASA 
NOVA, CARVALHO, 2012; NOGUEIRA, FADEL, TAKAMATSU, 2012) .

In the international scenario, researchers have been intensely discussing the gap between teachers who are academically prepared, with $\mathrm{PhDs}$, and professionally prepared teachers, holding professional certifications such as Certified Public Accountants (CPA).

Marshall et al. (2010) state that, over the last decade, there has been considerable discussion about the gap between education and accounting practices, and even if Accounting must be taught by doctors or by professional accountants with CPA certification. In other words, the relevance of the academic versus the vocational training of teachers in teaching Accounting is being discussed. In this regard, several scholars have devoted themselves to discuss this, without however reaching any consensus, not even apparently (ANNISETTE, KIRKHAM, 2007; BELL, FRECKA, SOLOMON, 1993; HARMER, 2009; KACHELMEIER, 2002; MACHADO, 2008a, 2008b; MARSHALL et al., 2010; NJOKU, HEIJDEN, INANGA, 2010; PIERRE et al., 2009). Marshall et al. (2010) carried out a survey amongst 95 American Accounting teachers who had PhDs and CPA credentials concerning teaching Accounting. Based on the investigated sample, the authors concluded that there is qualification able to substitute experience in teaching and in accounting practice when the intention is to become an efficient Accounting professor. In the same direction, Harmer (2009) states that courses in the field of business often provide simplified contents, that hardly consider the chaotic environment and the organic nature of accounting work. For the author, the difference between the academic representations of organizations and reality is a problem in several respects. Annisette and Kirkham (2007, p. 10) also support the hypothesis that "where the link between practice and research is nonexistent or weak (such as in the case of Accounting), university is of little use to a profession as a means of dissemination, expansion and development of relevant professional knowledge".
When discussing academic qualification, it appears that research plays an important role in the process of teaching and learning. Collier (1998 apud NJOKU, HEIJDEN, INANGA, 2010) states that there is a strong link between high quality education and relevant research, because, in addition to enhancing the professor's knowledge on the subject, the combination of teaching and research offers opportunities to pass on new information and enhances the intrinsic value of research. Kachelmeier (2002) states that research offers direct and indirect benefits to the teaching of Accounting. The direct benefit is the fact that research situates Accounting in the social context, giving students knowledge about who is interested in Accounting and why. The indirect benefit is even more useful and relevant. According to Kachelmeier (2002), research is a means by which teachers continually challenge each other to come up with new ideas and defend their own ideas rigorously. Without research or similar activities, professors are at risk of becoming obsolete, teaching yesterday's rules for tomorrow's challenges.

To Pierre et al. (2009), apart from the benefits research brings to the body of knowledge about education, it in general also makes individuals more inquisitive, more reflective, and better professors. So that research may have direct effects on learning, it must, however, be woven into the teaching practice itself. Those who do so are often more able to know and understand their students and the learning environment.

In this sense, findings provided by the study of Bell, Frecka and Solomon (1993, p. 47) demonstrate that "[...] consistent with other fields [of knowledge], there is a statistically reliable positive association between effectiveness in teaching Accounting and research productivity." However, there are drawbacks. Machado (2008a), analyzing the processes of knowledge construction, highlights the hegemony of Cartesian thought that is prevalent today - in which the method or path, when facing a complex task, in cognitive terms, is to decompose, analyze, reduce complex ideas to simple ones. To Machado (2008a, p. 23), "the price paid for this reduction comes quickly: 
the object of knowledge is reduced to fragments, emptying of its meaning". Also, according to the author, "[...] scientific research itself seems often illustrate a growing fragmentation of knowledge, without considering a comprehensive overview referring to the values involved", so that, "in certain fields, often uncritical overestimation of certain interdisciplinary specializations that mean little or nothing regarding the promotion of human freedom, seem to occur" (MACHADO, 2008a, p. 23).

When reviewing professional qualifications, its relevance is given in order to establish a "bridge" between current accounting practices and what is taught in the university, since pragmatic experience also gives the professor the right conditions to assign meaning to what he teaches. For Machado (2008a, p. 27), meanings “[...] are created by establishing relationships between objects, ideas and concepts. A meaning is like a bundle of relationships." This means that, in the classroom, "[...] meaning is created by talking about the topic, by making relevant, sometimes unsuspected, connections among different subjects". Thus, the process of signifying is intimately linked to the history of the knowledge that is being studied. There are, however, other ways of giving knowledge meaning, according to the author: "One way of revealing the significance of what we teach is to present some kind of application [...]" (MACHADO, 2008b, p. [3]). This approach is supported by Vasconcelos, who, concerning this subject, explains:

Once you consider [...] the "meaning" factor an item that facilitates the teaching-learning process for students, it is clear that the professor who has professional experience in the course's specific field of expertise will be a more up-to-date one, with a broader view of applying theory to the future occupational practice of their work (VASCONCELOS, 2009, p. 41).

Likewise, Volpato (2009) believes that, probably due to the ease with which professors relate theoretical knowledge and contents to their experiences, not only students but also professors themselves tend to value work in the professional field. To this author, the fundamental difference between teachers who are freelance Accounting professionals and all other professors is the value that the former attribute to their professional experiences, bringing them into the classroom. The knowledge and skills that reveal their basic professional activity define the mainstay of teaching and learning that they experience with their students.

In short, these discussions point to the need for three types of teaching qualifications in the field of teaching Accounting: pedagogical qualification, professional qualification and academic qualification.

\subsection{National Exam for the Assessment of Student Performance (Exame Nacional do Desempenho dos Estudantes/Enade)}

The Enade is a mandatory curriculum component, part of the Ministry of Education's Higher Education Evaluation System (Sistema de Avaliação do Ensino Superior/Sinaes), whose purpose is to assess student performance as to program content, skills and competencies.

The results of this evaluation are expressed through concepts in five-point scale, and the assessment is applied periodically, in sampling procedures, on students of undergraduate courses at the end of the first and final year, accompanied by a socioeconomic questionnaire. Periodicity of this assessment is of a maximum three years.

The Enade exam is made up of two groups of questions: a) general education, with ten questions; and b) specific components of the field, with 30 questions. The Enade grade is calculated by the weighted average of the standardized score of graduates in the specific component and the standardized score of graduates in general education. The part relating to the specific component corresponds to $75 \%$ of the final grade, while the one related to general education corresponds to $25 \%$, in line with the number of questions in the test (INEP, 2008). 
The Enade evaluation is, therefore, an assessment instrument that aims at making a diagnosis of students' skills and abilities over the years of graduation, in order to measure the added knowledge provided to the student by the course over time (VERHINE, DANTAS, SOARES, 2006). The Enade (of graduating students) is thus an objective indicator, working exclusively with student performance (ANDRADE, 2011).

\section{METHOD}

Gall, Gall and Borg (2007) believe that the goal of educational research is to generate knowledge that describe, make predictions and improvements and explain the processes and the practices related to education. In this study, to answer the research question and test the hypotheses, we used the descriptive strategy, because, according to the authors, this is the description of natural or social phenomena, their form, structure, activity, changes over time, relationship with other phenomena and so on (GALL, GALL, BORG, 2007).

This type of research, according to Gall, Gall and Borg (2007), depends strongly on the measuring and observation instruments, since, besides the description of the characteristics of a given population or phenomenon, the main objective of this approach is to establish relationships between variables and facts. Therefore, we chose to use questionnaires as an instrument for primary data collection. Questionnaires were sent to managers (coordinators, department heads and directors) of 902 courses in Accounting Sciences who underwent the Enade assessment in 2009.

\section{I Questionnaire structure}

The questionnaire was prepared with the following structure: (i) the institution's data; (ii) the respondent's data; (iii) constitutive factors of academic, professional and pedagogical qualifications; (iv) open reflections - a space where respondents could register other information they deemed relevant concerning teaching qualification in their respective institutions. The constitutive factors of academic, professional and pedagogical qualifications (item iii) were raised and characterized by Miranda (2011), by means of the Delphi technique.

Initially, there were two sessions of pre-tests to determine the quality of the survey instrument. The questionnaire was applied in two steps: (i) during the VI Meeting of Coordinators of Accounting Sciences Courses (VI Encontro de Coordenadores de Cursos de Ciências Contábeis), held between August 4 and 6, 2011, in Fortaleza (State of Ceará); and (ii) through an electronic questionnaire, hosted on Google Platform.

\subsection{Tabulation and analysis of received data}

Following data collection, descriptive statistical analysis was carried out, allowing for the identification of Higher Education Institution respondents (organization, administration, location, position of the respondent) and respective frequency of responses. Frequency of teaching formation institutional actions and teaching qualification items in the framework of Higher Education Institution respondents (quantity, minimum, average, maximum and standard deviation) were also identified. Next, we tested the hypotheses described in Table 1, by means of respective instruments.

\begin{tabular}{|l|l|}
\hline \multicolumn{1}{|c|}{ Hypotheses } & \multicolumn{1}{|c|}{ Instruments } \\
\hline $\begin{array}{l}\mathrm{H}_{1:} \text { the courses that presented the best results in the Enade assessment (CE) of graduating students are } \\
\text { those who also hold the best levels of qualification in the teaching infrastructure (academic, professional } \\
\text { and pedagogical) }\end{array}$ & Regression and Correlation \\
\hline $\mathrm{H}_{2:}$ There is significant positive correlation between Qpe and Qac & Correlation \\
\hline $\begin{array}{l}\mathrm{H}_{3}: \text { The Qac in the Higher Education Institutions is significantly higher than in private Higher Education } \\
\text { Institutions }\end{array}$ & Proportion Test \\
\hline
\end{tabular}

$\mathrm{Qac}=$ academic qualification; $\mathrm{Qpr}=$ professional qualification; $\mathrm{Qpe}=$ pedagogical qualification; $\mathrm{CE}=$ Enade grade (score of graduating students).

CHART 1 - Analysis hypotheses and instruments 


\section{ANALYSIS AND DISCUSSION OF RESULTS}

Adding up the answers obtained during the VI Meeting of Coordinators of Accounting Sciences Courses with the answers obtained in the electronic form, a total 357 questionnaires were handed in. Of this total, however, after careful analysis, 139 were excluded for the following reasons: repeated questionnaires (more than one answer per Higher Education Institution); answers from middle schools (accounting technicians - who attended the event in Fortaleza); answers without identification of Higher Education Institutions; questionnaires from Higher Education Institutions that lacked the Enade assessment in 2009; questionnaires with answers to only a few of the questions; and questionnaires with inconsistent answers. Thus, the sample was made up of 218 Higher Education Institutions, comprising $24.2 \%$ of HEIs with Enade assessment in 2009, in Brazil.

\section{I Descriptive statistics}

Survey respondents were mostly coordinators, directors and department heads, who together totaled $88 \%$ of respondents. In private Higher Education Institutions, respondents were predominantly coordinators; in public HEIs, they were department heads.
Geographically, the distribution of the sample was balanced; only the state of Roraima presented no valid responses. In the South, 55 institutions were investigated, the equivalent to 27.9\% of HEIs with Accountancy courses in the region. In the Southeast, on the other hand, 83 institutions were surveyed (22.9\% of the regional total); in the North, 16 HEIs (24.2\% of the HEIs in the region) were analyzed; in the Midwest region, 26 institutions (23, 36\% of the Midwest HEIs) were surveyed; and, in the Northeast, 38 institutions (22.8\% of HEIs located in the region) were looked into.

Amongst the 218 surveyed HEIs, 44 are institutions with public administrative dependence, i.e., 34.9\% of Brazilian public HEIs. Private institutions, on the other hand, totaled 174 HEIs, representing $22.4 \%$ of total Brazilian private HEIs, with Enade evaluation in 2009. Nearly half of the respondent institutions (49.1\%) is made up of colleges, representing $20.5 \%$ of the national colleges with courses in Accounting Sciences. Similarly, the HEIs in the form of universities (77) represent $27.8 \%$ of national universities with courses in Accounting Sciences, while University Centers (34) represent 33.7\% of HEIs with this type of academic organization.

Table 1 shows the Enade evaluation results (graduating students), in 2009, for the 218 higher education institutions with courses in Accounting Sciences that participated in this study.

TABLE 1 - Result of Enade evaluation by concept - Accounting Sciences course (2009)

\begin{tabular}{|c|c|c|c|c|c|}
\hline \multirow{2}{*}{$\begin{array}{l}\text { Enade concept } \\
\text { No concept }\end{array}$} & \multicolumn{2}{|c|}{ Amount investigated } & \multicolumn{2}{|c|}{ National amount } & \multirow{2}{*}{$\begin{array}{l}\text { Sample } \\
27.3 \%\end{array}$} \\
\hline & 47 & $21.6 \%$ & 172 & $19.1 \%$ & \\
\hline Grade 1 & 2 & $0.9 \%$ & 16 & $1.8 \%$ & $12.5 \%$ \\
\hline Grade 2 & 36 & $16.5 \%$ & 217 & $24.1 \%$ & $16.6 \%$ \\
\hline Grade 3 & 82 & $37.6 \%$ & 347 & $38.5 \%$ & $23.6 \%$ \\
\hline Grade 4 & 35 & $16.1 \%$ & 118 & $13.1 \%$ & $29.7 \%$ \\
\hline Grade 5 & 16 & $7.3 \%$ & 32 & $3.5 \%$ & $50.0 \%$ \\
\hline Total & 218 & $100 \%$ & 902 & $100 \%$ & $24.2 \%$ \\
\hline
\end{tabular}

Source: The authors.

According to Table 1, the absolute amount of HEI respondents with concepts is greater in the range of concepts 2, 3 and 4 . In relative terms, we can observe that the sample included $27.3 \%$ of the HEIs without a concept, whereas the response rate from HEIs with a concept was increasing, as 
shown in the last column of Table 1. A possible explanation for this trend is the fact that HEIs with larger concepts would not be afraid (on the contrary!) to disclose information about their teaching staff (GALL, GALL, BORG, 2007).

\subsection{Teaching qualifications}

Table 2 presents the factors relating to the qualifications (academic, professional and pedagogical) of the teaching staff in the investigated HEIs, the amount of respondent
HEIs, the minimum, average, maximum percentages and the standard deviation. To calculate the percentage, respondents were asked to inform the number of professors who taught classes with accounting contents for the course, in 2011, as well as the amount of professors who presented the attributes listed in Table 2. Dividing the number of professors referring to each of the items investigated by the total sum of professors who taught classes in that year, we obtained the proportion of teaching staff in each HEI which presented each of the attributes investigated.

TABLE 2 - Teaching staff qualification items - Accounting Sciences courses in Brazil (2009)

\begin{tabular}{|c|c|c|c|c|c|}
\hline Variables & $\begin{array}{l}\text { Amount } \\
\text { HEI }\end{array}$ & Min. & Average & Max. & $\begin{array}{l}\text { Standard } \\
\text { deviation }\end{array}$ \\
\hline \multicolumn{6}{|l|}{ ACADEMIC QUALIFICATION } \\
\hline Proportion of PhD professors & 218 & $0 \%$ & $7 \%$ & $81 \%$ & $13 \%$ \\
\hline Proportion of $\mathrm{PhD}$ professors with a minimum Masters degree & 218 & $0 \%$ & $44 \%$ & $88 \%$ & $25 \%$ \\
\hline $\begin{array}{l}\text { Articles in international scientific journals or with Qualis/CAPES }=\mathrm{A} 1 \text {, } \\
\mathrm{A} 2, \mathrm{~B} 1 \text { or } \mathrm{B} 2\end{array}$ & 182 & $0 \%$ & $14 \%$ & $100 \%$ & $23 \%$ \\
\hline $\begin{array}{l}\text { Articles in journals with Qualis up to B3, including the latter, or not classified } \\
\text { in Qualis }\end{array}$ & 178 & $0 \%$ & $24 \%$ & $100 \%$ & $27 \%$ \\
\hline Participate in research groups & 203 & $0 \%$ & $21 \%$ & $100 \%$ & $21 \%$ \\
\hline Participate regularly in scientific events of the accounting field & 213 & $0 \%$ & $34 \%$ & $100 \%$ & $28 \%$ \\
\hline $\begin{array}{l}\text { Participate in research associations or organizations, i.e.: Anpad, AN- } \\
\text { PCONT, Capes }\end{array}$ & 215 & $0 \%$ & $7 \%$ & $71 \%$ & $13 \%$ \\
\hline Have applied research projects in the educational/market Accounting field & 218 & $0 \%$ & $19 \%$ & $90 \%$ & $20 \%$ \\
\hline \multicolumn{6}{|l|}{ PROFESSIONAL QUALIFICATION } \\
\hline Participate regularly in professional events of the Accounting field & 214 & $0 \%$ & $47 \%$ & $100 \%$ & $30 \%$ \\
\hline $\begin{array}{l}\text { Have at least two years of experience in Accounting, not counting the } \\
\text { academic field }\end{array}$ & 215 & $0 \%$ & $74 \%$ & $100 \%$ & $28 \%$ \\
\hline $\begin{array}{l}\text { Have experience as consultants, in agencies or as technical referees in the } \\
\text { Accounting field }\end{array}$ & 216 & $0 \%$ & $54 \%$ & $100 \%$ & $29 \%$ \\
\hline Are experienced in the business management field & 214 & $0 \%$ & $52 \%$ & $100 \%$ & $28 \%$ \\
\hline Have professional certification in the Accounting field (CRC) & 208 & $8 \%$ & $76 \%$ & $100 \%$ & $26 \%$ \\
\hline Have CVM independent auditor certification & 218 & $0 \%$ & $5 \%$ & $36 \%$ & $8 \%$ \\
\hline $\begin{array}{l}\text { Have international professional certifications such as: Certified Public Accountants } \\
\text { (CPA), Certified Management Accountant (CMA) or Association of Chartered } \\
\text { Certified Accountants (ACCA) }\end{array}$ & 217 & $0 \%$ & $1 \%$ & $22 \%$ & $3 \%$ \\
\hline Have extension projects involving academy and community & 215 & $0 \%$ & $15 \%$ & $67 \%$ & $16 \%$ \\
\hline \multicolumn{6}{|l|}{ PEDAGOGICAL QUALIFICATION } \\
\hline Participate regularly in events of the Accounting field & 210 & $0 \%$ & $41 \%$ & $100 \%$ & $38 \%$ \\
\hline Have two years' experience as higher education professors & 211 & $11 \%$ & $89 \%$ & $100 \%$ & $18 \%$ \\
\hline Have research projects that are specifically related to teaching & 217 & $0 \%$ & $10 \%$ & $83 \%$ & $13 \%$ \\
\hline Have pedagogical formation lato sensu courses specifically in EDUCATION & 209 & $0 \%$ & $12 \%$ & $71 \%$ & $15 \%$ \\
\hline $\begin{array}{l}\text { Have extension courses for teacher training, such as university pedagogy } \\
\text { and courses about new educational technologies, amongst others }\end{array}$ & 218 & $0 \%$ & $18 \%$ & & $27 \%$ \\
\hline
\end{tabular}

Source: The authors 
According to Table 2, the "Proportion of $\mathrm{PhD}$ professors" presented an average percentage of only $7 \%$ of the teaching staff in investigated HEIs. Consequently, average publication of articles was also small. Only $14 \%$ of teaching staff in investigated HEIs published articles in international scientific journals or with Qualis/ CAPES A1, A2, B1 or B2, and 24\% have articles in other journals. Similarly, participation in research groups is also small, with only $21 \%$ of professors.

The percentages relative to experience in the Accounting profession and to credentials from the Regional Accounting Council were high, on the other hand; however, having international credentials (1\%) and CVM auditor credentials $(5 \%)$ was relatively low.

The variables related to teaching qualification were almost all very low, three of them below 20\%, namely: "Have research projects specifically related to education" $(10 \%)$,

"Have pedagogical formation lato sensu courses specifically in Education" (12\%), and "have extension courses for teacher training (examples: teaching university courses on new educational technologies, amongst others)" (18\%).

\subsection{Enade of Accounting Sciences courses}

Graph 1 shows the average teaching qualifications by region compared to the average of Enade evaluation results (\%), by region in Brazil. Unlike previous analyses, which contemplated the 218 respondents HEIs, the information below refers only to the 171 HEIs with concepts in the Enade evaluation in 2009.

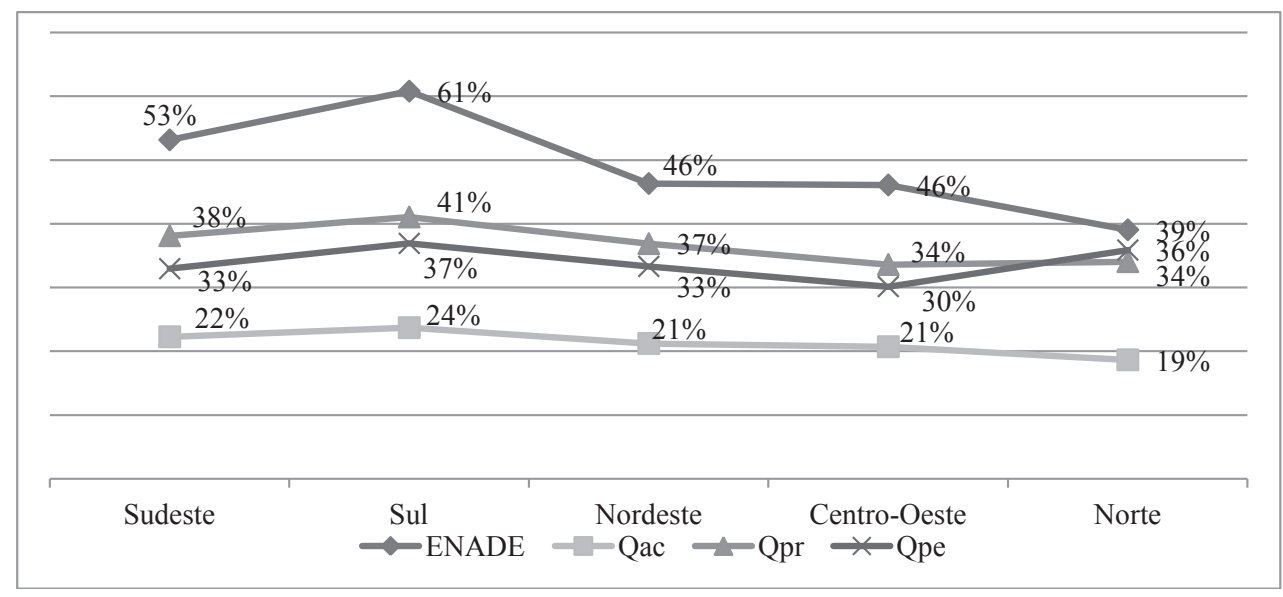

GRAPH 1 - Teacher qualifications and Enade by region

Source: The authors.

According to Graph 1, the South has the highest average Enade results, and was also the region with the highest average academic, professional and pedagogical qualifications (for the $171 \mathrm{HEI}$ with concepts in the Enade evaluation). Then comes the Southeast, with the second highest average Enade, and the second largest averages of academic and professional qualifications. The lowest averages in the Enade evaluation and academic qualification occurred in the North. Please observe, too, that, in this region, pedagogical and professional qualifications take on trends that are contrary to those of the Enade result.

\subsection{Result of multiple linear regression}

The hypothesis test for the significance of regression aims at discovering if there is a linear relationship between the variable of answer $y$ 
(Enade concept) and the set of regresses Qac $\left(x_{1}\right)$, Qpr $\left(x_{2}\right)$ and Qpe $\left(x_{3}\right)$. The appropriate hypotheses are:

$H_{0}: \beta_{1}=\beta_{2}=\beta_{3}=0$ versus $H_{1}: \beta_{j} \neq 0$ for the minimum $\mathrm{j}, \mathrm{j}=1,2,3$.
According to Table 3, which presents the analysis of variance, $\mathrm{H}_{0}$ is rejected, i.e., there is at least a significant variable in the model.

TABLE 3 - Analysis of variance

\begin{tabular}{cccccc}
\hline Model & $\mathbf{G L}^{(\mathbf{1})}$ & SQ $^{(\mathbf{1})}$ & $\mathbf{Q M}^{(3)}$ & $\mathbf{F}^{(4)}$ & $\mathbf{p}^{\text {-value }}$ \\
\hline Regression & 3 & 24.938 & 8.313 & 13.932 & $<0.000$ \\
Residual & 167 & 99.646 & .597 & & \\
\hline Total & 170 & 124.585 & & & \\
\hline
\end{tabular}

${ }^{(1)} \mathrm{GL}$ : is the number of grades of freedom; ${ }^{(2)} \mathrm{SQ}$ : sum of the square; ${ }^{(3)} \mathrm{QM}$ : Average Square (variance); ${ }^{(4)} \mathrm{F}$ : value of statistic F; ${ }^{(5)}$ p-value: value of probability of obtaining the observed effect (or a less probable value), given that the null hypothesis is true.

Source: The authors.

Table 4 presents the coefficients presented by regression. One can see that only the academic qualification was significant at the 5\% level $(\mathrm{p}$-value $=0.000)$. Other qualifications are not statistically significant, and for one of them (pedagogical qualification), the estimator is negative.

TABLE 4 - Statistics referring to the estimated regression model.

\begin{tabular}{cccc}
\hline Parameters & Estimates $^{(1)}$ & $\mathbf{t}^{(2)}$ & p-value \\
\hline Intercept $\left(\beta_{0}\right)$ & 2.222 & 11.065 & $<0.000$ \\
Qpr $\left(\beta_{1}\right)$ & 0.332 & 0.643 & 0.521 \\
Qpe $\left(\beta_{2}\right)$ & -0.914 & -1.829 & 0.069 \\
Qac $\left(\beta_{3}\right)$ & 2.487 & 5.946 & $<0.000$ \\
\hline
\end{tabular}

${ }^{(1)}$ Estimates: parameter estimates; ${ }^{(2)} \mathrm{t}$ : value of statistic $\mathrm{t}$

Source: The authors

Based on Table 4, we can observe that only the Qac variable is significant at the 5\% level, i.e., the Enade variable establishes a significant linear relationship only with the Academic Qualification (Qac) variable. Therefore, to get a sense of the real relationship between Enade performance and Academic Qualification, we adjusted the following model, where $\mathrm{E}$ is the error term:

$$
\text { Enade }=\beta_{0}+\beta_{1} Q a c .+E
$$

TABLE 5 - Model Summary

\begin{tabular}{ccccc}
\hline Parameters & Estimates & p-value & $\mathbf{R}^{2}$ & $\mathbf{R}_{\text {Adjusted }}$ \\
\hline Intercept $\left(\beta_{0}\right)$ & 2.0551 & $<0.000$ & 0.184 & 0.179 \\
$\operatorname{Qac}\left(\beta_{l}\right)$ & 2.4448 & $<0.000$ & & \\
\hline
\end{tabular}

Source: The authors. 
The assumptions for the above model are: normality and homoscedasticity of residuals, and no collinearity amongst variables. To test the normality of the residuals in the adjusted model, we used the Kolmogorov-Smirnov and Shapiro Wilk tests. According to these tests, at the $1 \%$ significance level, residuals have normal distribution (in both tests), since the p-values (0.023 and 0.051 , respectively) were higher than $1 \%$.

According to Favero et al. (2009, p. 357), the problem of heteroscedasticity occurs because “[...] some residuals may present correlation with one (or even more) explanatory variable, and, thus, may vary depending on it". To Favero et al. (2009, p 377-378), the heteroscedasticity can be tested using the Glejser test, "[... ] regressing the terms of the error for each one of the explanatory variables in various forms [linear, logarithmic and inverse]". When carrying out this test, for this research it was found that there is no relationship between the explanatory variable $\mathrm{Qac}$ and terms of the error obtained in the multiple regression model, revealing that there is no heteroscedasticity.

The problem of multicollinearity, which is a high correlation between explanatory variables, did not occur, because there was only one significant explanatory variable in the model, the
Qac. In this case, both statistics, VIF (Variance Inflation Factor) and Tolerance are equal to 1.000.

The explanatory power of the model ( R2 ) is small, as shown in Table 5, which occurs due to the fact that other variables related to student performance have not been included in this study because they are not part of the teaching qualifications, because "several factors beyond the control of schools affect student achievement: family background, individual ability, historical factors in the student's educational history and quality/education of classmates" (ANDRADE, 2011, p. 335 ), internal factors, such as HEI infrastructure (libraries, laboratories, classroom environment) and pedagogical program ASSOCIATION TO ADVANCE COLLEGIATE SCHOOLS OF BUSINESS - AACSB, 2010; INEP, 2008).

\subsection{Correlation results}

To test the correlation between academic, professional and pedagogical qualifications and Enade, we carried out the test of normality for the three qualifications. As there was no normality, we used Spearman's non-parametric correlation test (Table 6).

TABLE 6 - Correlations: teaching qualifications and Enade - Spearman's test

\begin{tabular}{|c|c|c|c|c|c|}
\hline Variables & & Enade & Qac & Qpr & Qpe \\
\hline \multirow{3}{*}{ ENADE } & Correlation coefficient & 1 & & & \\
\hline & $\mathrm{p}$-value & . & & & \\
\hline & $\mathrm{N}$ & 171 & & & \\
\hline \multirow{3}{*}{ Qac } & Correlation coefficient & $.445^{* *}$ & 1 & & \\
\hline & $\mathrm{p}$-value & .000 & . & & \\
\hline & $\mathrm{N}$ & 171 & 171 & & \\
\hline \multirow{3}{*}{ Qpr } & Correlation coefficient & .138 & $.326^{* *}$ & 1 & \\
\hline & $\mathrm{p}$-value & .072 & .000 & . & \\
\hline & $\mathrm{N}$ & 171 & 171 & 171 & \\
\hline \multirow{3}{*}{ Qpe } & Correlation coefficient & -.007 & $.242^{* *}$ & $.450^{* *}$ & 1 \\
\hline & $\mathrm{p}$-value & .926 & .001 & .000 & . \\
\hline & $\mathrm{N}$ & 171 & 171 & 171 & 171 \\
\hline
\end{tabular}

** Significant correlation at the $1 \%$ level.

Source: The authors. 
According to Table 6 , there was a significant positive correlation between the Qac index and Enade test results in graduating students, which allows us to state that the higher the level of academic qualification of the institution's teaching staff, the higher the grades of graduating students in the Enade result. This result implies that the learning performance is linked to academic qualifications (degree, research, articles etc.) of the teaching staff, as recommended by literature.

Consistent with these results, findings provided by the study of Bell, Frecka and Solomon (1993, p. 47) demonstrate that "[...] consistent with other fields [of knowledge], there is a statistically reliable positive association between efficiency in teaching of Accounting and research productivity". Similarly, Collier (1998, apud NJOKU, HEIJDEN, INANGA, 2010) also states that there is a strong link between high quality teaching and relevant research. The statement below reiterates this understanding ${ }^{1}$.

Unfortunately, HEIs do not encourage scientific research projects, and also do not support professors in order to enable full dedication. Most HEI professors teach for the love of teaching. Teaching is seen as a second job. Since the wages of HEI professors are low, they do not for allow exclusive devotion, even as a matter of survival (DATA OF INTERVIEWS, 2011).

The words of the respondent above demonstrate his understanding that the quality of the course is linked to the academic qualifications of the teaching staff, and that, in this particular case, there is no institutional support.

There was not, however, a significant positive correlation between the Qpr index and the Enade results, as expected. Thus, one cannot say that an institution with higher levels of qualification has better results in terms of student performance (measured by the Enade exam).

In this research, we found, also, that there is no significant positive correlation between the
Qpe index and student performance (measured by the Enade result). Thus, one cannot say that an institution whose teaching staff has high educational qualifications is going to lead its students to better levels of performance, contrary to "cries" by education researchers.

Given these results, it can be said that the hypothesis " $\mathrm{H} 1$ : courses with the highest results in the Enade evaluation of graduating students are those who also have the highest levels of qualification of the teaching staff (academic, professional and pedagogical)" was accepted only partially, i.e., only the academic qualification is linked to student performance as measured by Enade.

The hypothesis " $\mathrm{H}_{2}$ : There is a significant positive correlation between the Qpe e a Qac" was accepted. Professors with the highest levels of pedagogical qualifications also have higher levels of academic qualification. This result may mean that professors with the highest levels of teacher training are led to reflect about their activity, as the authors who value the so-called "reflective professor" point out (PIMENTA, ANASTASIOU, 2002; SCHÖN, 2000).

Table 6 shows other positive correlations: between academic qualification and professional qualification, and between pedagogical qualification and professional qualification, i.e., all qualifications have positive correlations with each other, indicating that HEIs with the highest rates in one qualification also have the highest rates in others.

By correlating the variables themselves (which make up the teaching qualifications) against the Enade result, we found in this research that all variables components of academic qualification were significantly correlated to Enade, whereas the professional qualification presented two variables related to Enade (applied research and extension projects). Pedagogical qualification, on the other hand, showed no positively and significantly correlated variable with Enade. 


\subsection{Proportion test results}

The test of proportions was used to test the hypothesis "H3: The Qac in public HEIs is significantly higher than in private HEIs". Amongst the 171 institutions in the sample that had Enade concepts in the evaluation, in 2009, 40 are public and 131 are private HEIs.

Initially the Kolmogorv-Smirnov test was carried out to assess the normality of the data, verifying that, at the significance level of $1 \%$, the normality assumption was met for all variables.

Table 7 presents averages, standard deviation and standard error of the constituent factors of academic, professional and pedagogical qualifications, of public and private HEIs, necessary for the proportions test.

TABLE 7 - Descriptive statistics

\begin{tabular}{cccccc}
\hline & Variables & N & Average & Standard deviation & Standard error \\
\hline \multirow{2}{*}{ Qac } & public HEIs & 40 & 0.3273 & 0.16570 & 0.02620 \\
& private HEIs & 131 & .01931 & 0.13283 & 0.01161 \\
\hline \multirow{2}{*}{ Qpr } & public HEIs & 40 & .03452 & 0.10902 & 0.01724 \\
& private HEIs & 131 & .03869 & 0.13742 & 0.01201 \\
\hline \multirow{2}{*}{ Qpe } & public HEIs & 40 & 0.2805 & 0.09425 & 0.01490 \\
& private HEIs & 131 & 0.3449 & 0.13709 & 0.01198 \\
\hline
\end{tabular}

Source: The authors.

Table 8 shows the confidence intervals for each of the three qualifications in public and private institutions.

TABLE 8 - Interval for difference between proportions between qualification in public and private institution

\begin{tabular}{c|cc}
\hline \multirow{2}{*}{ Qualification } & \multicolumn{2}{|c}{$\operatorname{IC}_{90 \%}\left(P_{P u b}-P_{\text {Priv }}\right)$} \\
& Inferior limit & Superior limit \\
\cline { 2 - 3 } & 0.0024 & 0.2576 \\
Academic & -0.1759 & 0.0959 \\
Professional & -0.1889 & 0.0689 \\
Pedagogical & & \\
\hline
\end{tabular}

Source: The authors.

Through the decision rule presented above and the confidence intervals (Table 8), one can say with $90 \%$ confidence that there is a significant difference only for Academic Qualification, i.e., the highest proportion of qualified professors is academically concentrated in public institutions. Amongst the 40 public higher education institutions in the sample, 37 are universities, i.e., the highest level of academically qualified is concentrated in public institutions. The words of certain respondents corroborate these findings.

In the state of Maranhão, we have few masters in Accounting Sciences, and they are absorbed by the Federal University, however, teachers who teach accounting classes are all experts in the market (DATA OF INTERVIEWS, 2011). 
Since we are a private HEI, the focus is much more on the market than in the survey, but we are working to transform this reality. Some professors are already participating in the Master's selection process (DATA OF INTERVIEWS, 2011).

These results support Morosini's understanding (2000), for which the greater part of research occurs effectively in public institutions. The main vocation of private HEIs is focused on teaching.

Note, also, in Table 7, that the average of professional qualification in private HEIs are larger than in public HEIs $(0.3869 \times 0.3452)$. Although this difference is not statistically significant, the difference in averages presented is consistent with the results presented in the hypothesis test $\mathrm{H} 2$, because if the majority of the teaching staff of public HEIs is involved in research, it is expected that their performance in the market is also smaller.

\subsection{Discussion of results}

It is interesting to note that the mechanisms of evaluation of institutions, professors and students, both in Brazil and in the international scenario (ANNISETTE, KIRKHAM, 2007; INEP, 2008; KACHELMEIER, 2002; NJOKU, HEIJDEN, INANGA, 2010; PIERRE et al. 2009; RUFF, THIBODEAU, BERDARD, 2009), are heavily focused on scientific production, which often has been the subject of criticism by many scholars (ALMEIDA, PIMENTA, 2009; EZCURRA, 2007). When analyzing student performance (as in this study), however, we can observe that it is exactly research which necessarily involves degrees that provides the best performance of students .

It was surprising to find that the professional and pedagogical qualifications of professors who teach Accounting in Brazil are not statistically related to student performance, considering the arguments presented in literature.

This result leads to some thought. It is known that Enade does not take into account the institution's mission, as recommended by AASCB. This implies that this examination (Enade) is eminently quantitative, and does not consider the specificities and diversity of projects in the evaluation processes. Analyzed from this angle, one can imagine that, because it quite generic, this test is unable to capture the peculiarities of the field, as the AACSB does, since it has criteria, mainly qualitative and specific for the business area.

Another explanation that is considered for these results is the possibility of pedagogical and professional qualifications not being adequately represented by the factors validated in the Delphi technique. With regard to the pedagogical qualification, the AACSB understands that the factors that make it up are actually attributes of academic qualification. So much so that, to that institution, there are only two types of qualifications: academic and professional.

As to the composition of professional qualification, according to data from AACSB, there is no minimum percentage required for the teaching staff. It is established only the HEI must have at least $50 \%$ of its teaching staff qualified academically and that the two qualifications together (academic and professional) should reach $90 \%$ of the total score of the teaching staff, but does not establish a minimum professional qualification. This means that, theoretically, the HEI could have only academically qualified teachers. In practice, professional qualification is, on average, half of the academic qualification in HEIs accredited by AACSB (2010).

It also appears that, in the foreign scenario (USA and England), there are other factors that strengthen professional qualification: (a) strong professional credentials (CPA, CMA, ACCA), which, to be obtained, require courses of at least 150 hours, as well as the sufficiency examination that is already established in those countries. Although Brazil is heading in that direction, the initiative is still shy, as compared to the AngloSaxon world; (b) relevant published articles and minimum Master's degree, complemented by further research on the area taught by the professor. In Brazil, due to the small number of professors with stricto sensu degree, a Master's 
degree was considered an attribute of academic qualification, and not a professional one (as recommended by AACSB). Thus, it is clear that, because the Accounting field, in scientific terms, is rather young in the Brazilian scenario, professional qualification was restricted in this study almost exclusively to technical performance.

To improve professional qualification, amongst other things, investments must be made also in degrees and research. Capes has signaled its intention to strengthen professional qualification, since it has been encouraging, over recent years, the establishment of stricto sensu postgraduate studies focused on this segment - professional Master's degrees.

It can be argued that the main variable of academic qualification is a $\mathrm{PhD}$, because it is based on this degree that the professor becomes truly prepared for research and other activities related to it, as recommended by AACSB. Accordingly, the average percentage of doctors from public investigated HEIs is $15.52 \%$, whereas in private HEIs this percentage is only $4.89 \%$ of the teaching staff. This small amount of doctors (researchers) in private HEIs partly explains the low levels of the other variable components of academic qualification. Thus, this study found what some researchers claim, that is, research occurs effectively in public institutions (MOROSINI, 2000) - in this case, in public universities, since 37 of the 40 public higher education institutions investigated are universities. It is necessary, however, to emphasize that research does not only explain the difference in student performance between public and private institutions. Public universities, because they the most competitive selection processes, ultimately select students that are potentially more prepared, which can contribute to the average results of the institution also being higher, since performance in the evaluation of students entering Enade presents the correlation coefficient with the Enade result of students graduating at 0.579 (Pearson coefficient) for the investigated sample.

Therefore, jointly analyzing the results, we have: academic qualification is the only one that is significantly and positively associated with the
Enade; public HEIs represent only $23.4 \%$ of the sample investigated, but it is in them that research does occur (according to $\mathrm{H}_{3}$ ), that is, the fact that there are few HEIs with higher levels of academic qualification (public) explains, in part, the low performance of Accounting Sciences students in Enade. Accordingly, so that private HEIs, which are a majority amongst higher education institutions, may improve student performance, an indicated path is investing in the academic qualification of the teaching staff, especially in degrees. If such an investment occurs, levels of student performance may certainly be leveraged.

\section{FINAL CONSIDERATIONS}

The purpose of this research was to investigate the relationship between student performance and teacher qualification in Brazilian undergraduate Accounting Sciences courses, supposing the need for three types of qualification for the professor who teaches Accounting: academic, professional and pedagogical.

Initially, we found that the South had the highest average Enade results and is also the region with the highest average academic, professional and pedagogical qualifications for the investigated sample. Then comes the Southeast, which has the second highest Enade average, and the second largest average of academic and professional qualifications. The lowest averages in Enade evaluation and academic qualification occurred in the North.

When testing hypotheses, we found that the " $\mathrm{H}_{1}$ : courses with the highest results in the Enade evaluation of graduating students are those who also have the highest levels of teaching staff qualification (academic, professional and pedagogical)" was accepted partially, because only academic qualifications showed a significant regression coefficient at the $5 \%$ level (p-value = $0.000)$ and significant positive correlation at the $1 \%$ level with Enade results.

These results reveal the importance of policies that strengthen stricto sensu postgraduate studies in Accounting Sciences in Brazil, especially 
in regions where programs are still very few or almost non-existent, such as the North. Moreover, we highlight the importance of valuing professors, so that this positively reflects on students. Therefore, it is necessary that the valuing of professors go beyond the level of theory - the professor must be valued in terms of wages and working conditions, since there are already other important studies indicating the difference a good professor makes in a student's life (CHETTY, FRIEDMAN, ROCKOFF, 2011). It is also important that the professor pursue continued academic training, notably through research because the master, in the words of the late João Guimarães Rosa, "is not he who always teaches, but who suddenly learns".

Finally, since the aim of this study was to investigate teaching qualifications Accounting Sciences in Brazil, focusing on breadth rather than depth, the study subjects were people who would, theoretically, be able to provide the information collected relating to the teaching staff of their respective institutions. In this sense, the fact that we did not directly investigate teachers themselves is a limitation in this research. Another limitation refers to scope of Enade itself, which is not mandatory for state public institutions. Thus, important institutions such as the University of São Paulo (Universidade de São Paulo/USP) were left out of the sample. For future research, we suggest this research is applied directly to professors themselves, in order to make comparisons with the results of this study.

\section{NOTAS}

1. Please note that excerpts from interviews to be presented later on, in this article, do not indicate interviewees, since, for ethical reasons, a commitment was made as to preserving the identity of each one of them when carrying out this research.

\section{REFERENCES}

ALMEIDA, M. I.; PIMENTA, S. G. Pedagogia universitária: valorizando o ensino e a docência na Universidade de São Paulo. In:
(Orgs.). Pedagogia universitária. São Paulo: Edusp, 2009. p. 13-37.

ANDERE, M. A.; ARAUJO, A. M. P. Aspectos da formaçáo do professor de ensino superior de ciências contábeis: uma análise dos programas de pós-graduação. Revista de Contabilidade e Finanças, São Paulo, v. 19, n. 48, p. 91-102, set./ dez., 2008.

ANDRADE, E. C. Rankings em educação: tipos, problemas, informaçóes e mudanças: análise dos principais rankings oficiais brasileiros. Estudos Econômicos, São Paulo, v. 41, n. 2, p. 323-343, 2011.

ANNISETTE, M.; KIRKHAM L. M. The advantages of separateness explaining the unusual profession-university link in English Chartered Accountancy. Critical Perspectives on Accounting, London, n. 18, v. 1, p. 1-30, Jan. 2007.

ASSOCIATIONTO ADVANCE COLLEGIATE SCHOOLS OF BUSINESS - AACSB. Eligibility procedures and accreditation standards for business accreditation. 2010. Disponível em: <http://www.bond.edu.au/prod_ext/ groups/public/@pub-btsd-gen/documents/ genericwebdocument/bd3_013836.pdf>. Acesso em: 20 ago. 2010.

BELL, T. B.; FRECKA, T.; SOLOMON, I. The relation between research productivity and teaching effectiveness: empirical evidence of accounting educators. Accounting Horizons, Sarasota, v. 7, n. 4, p. 33-49, Dec. 1993.

BRASIL. Decreto n. $\mathbf{5 . 7 7 3}$, de 9 de maio de 2006. Dispóe sobre o exercício das funções de regulação, supervisão e avaliação de instituiçôes de educaçáo superior e cursos superiores de graduação e sequenciais no sistema federal de ensino. Disponível em: <http://www.planalto. gov.br/ccivil_03/_ato2004-2006/2006/decreto/ d5773.htm>. Acesso em: 22 abr. 2011.

BRASIL. Lei n. 12.249, de 11 de junho de 2010. [...] Altera o Decreto-Lei no 9.295, de 27 de maio de 1946 [...]. Disponível em: <http://www. planalto.gov.br/ccivil_03/_ato2007-2010/2010/ lei/112249.htm>. Acesso em: 22 abr. 2011.

CATAPAN, A.; COLAUTO, R. D.; SILLAS, E. P. Percepção dos discentes sobre os docentes exemplares de contabilidade em IES públicas e 
privadas. RIC: revista de informação contábil, Recife, v. 6, n. 2, p. 63-82, abr./jun. 2012.

CHETTY, R.; FRIEDMAN, J. N.; ROCKOFF, $\mathrm{J}$. The long-term impacts of teachers: teacher valueadded and student outcomes in adulthood. NBER Working Paper Series, n.17699, Cambridge, Dec. 2011. Disponível em: <http://obs.rc.fas. harvard.edu/chetty/value_added.pdf $>$. Acesso em: 22 abr. 2011.

CUNNINGHAM, B. M. Using action research to improve learning and the classroom learning environment. Issues in Accounting Education, Sarasota, v. 23, n. 1, p. 1-30, Feb. 2008.

EZCURRA, A. M. Los estudiantes de nuevo ingreso: democratización y responsabilidad de las instituciones universitarias. Cadernos de Pedagogia Universitária, São Paulo, n. 2, set. 2007.

FÁVERO, L. P. et al. Análise de dados: modelagem multivariada para tomada de decisóes. Rio de Janeiro: Elsevier, 2009.

FRANCO, M. A. S. Prática docente universitária e a construçáo coletiva de conhecimentos: possibilidades de transformaçóes no processo ensino-aprendizagem. Cadernos de Pedagogia Universitária, São Paulo, n. 10, set. 2009.

FRECKA, T. J.; RECKERS, P. M. J. Rekindling the debate: what's right and what's wrong with masters of accountancy programs: the staff auditor's perspective. Issues in Accounting Education, Sarasota, v. 25, n. 2, p. 215-226, May 2010.

GALL, M. D.; GALL, J. P.; BORG, W. R. Educational research: an introduction. 8th ed. Boston: Pearson/Allyn and Bacon, 2007.

GEARY, W.; KUTCHER, E. J.; PORCO, B. M. Partnering with practice: staffing to achieve excellence. Accounting Education, London, v. 25, n. 2, p. 199-213, May 2010.

GRADVOHL, R. F.; LOPES, F. F. P.; COSTA, F. J. O perfil do bom professor de contabilidade: uma análise a partir da perspectiva de alunos de curso de graduação. In: CONGRESSO USP CONTROLADORIA E CONTABILIDADE, 9., 2009, São Paulo. Anais eletrônicos... São Paulo: FEA-USP, 2009. Disponível em: <http:// www.congressousp.fipecafi.org/artigos92009/45. pdf>. Acesso em: 22 ago. 2010.
HARMER, B. M. Teaching in a contextual vacuum: lack of prior workplace knowledge as a barrier to sense making in the learning and teaching of business courses. Innovations in Education and Teaching International, London, v. 46, n. 1, p. 41-50, 2009.

INSTITUTO NACIONAL DE ESTUDOS E PESQUISAS EDUCACIONAIS ANÍSIO TEIXEIRA - INEP. Cálculo do conceito ENADE. 2008. Disponível em: < http:// download.inep.gov.br/download/enade/2008/ conceito_enade_final_corrigida_17_12_2009. pdf>; Acesso em: 22 abr. 2011.

Resumo técnico: censo do ensino superior de 2009. Brasília, 2010. Disponível em: <http://download.inep.gov.br/download/ superior/censo/2009/resumo_tecnico2009.pdf>. Acesso em: 18 ago. 2010.

KACHELMEIER, S. J. In defense of accounting education. The CPA Journal, New York, v. 72, n. 10 , p. 34-38, Oct. 2002.

LIBÂNEO, J. C. Conteúdos, formação de competências cognitivas e ensino com pesquisa: unindo ensino e modos de investigaçáo. Cadernos de Pedagogia Universitária, São Paulo, n. 11, out. 2009.

MACHADO, N. J. Imagens do conhecimento e ação docente no ensino superior. Cadernos de Pedagogia Universitária, São Paulo, n. 05, jun. 2008a.

. Mateologia, zero. Matemática dez. Pátio: revista pedagógica, Porto Alegre, v. 12, n. 47, p. $12-15$, out. 2008 b.

MARSHALL, P. D. et al. The accounting education gap. The CPA Journal, New York, v. 80 , n. 6, p. 8-10, June 2010.

MILEY, F. The storytelling project: innovating to engage students in their learning. Higher Education Research \& Development, Melbourne, v. 28, n. 4, p. 357-369, Aug. 2009.

MIRANDA, G. J. Docência universitária: uma análise das disciplinas na área da formação pedagógica oferecidas pelos programas de pós-graduação stricto sensu em ciências contábeis. REPEC, Brasília, v. 4, n. 2, p. 81-98, maio/ago. 2010.

Relaçóes entre as qualificaçóes do professor e o desempenho discente nos cursos 
de graduaçáo em contabilidade no Brasil. 2011. 211 f. Tese (Doutorado em Ciências Contábeis) - Programa de Pós-Graduação em Ciências Contábeis, Faculdade de Economia, Administração e Contabilidade, Universidade de São Paulo, São Paulo, 2011.

- $-\ldots-$; CASA NOVA, S. P. C; CORNACCHIONE, E. B. Os saberes dos professores referência no ensino de Contabilidade. Revista de Contabilidade \& Finanças, São Paulo, v. 23, n. 59, p. 142-153, maio/ago. 2012.

MOROSINI, M. C. Docência universitária e os desafios da realidade nacional. In: (Org.).

Professor do ensino superior: identidade, docência e formação. Brasília: Instituto Nacional de Estudos e Pesquisas, 2000. p. 11-20.

NJOKU, J. C.; HEIJDEN, B. I. J. M.; INANGA, E. L. Fusion of expertise among accounting faculty: towards an expertise model for academia in accounting. Critical Perspectives on Accounting, London, v. 21, n. 1, p. 51-62, Jan. 2010.

NOGUEIRA, D. R.; CASA NOVA, S. P. C.; CARVALHO, R. C. O. O bom professor na perspectiva da geração Y: uma análise sob a percepção dos discentes de ciências contábeis. Enfoque: reflexão contábil, Maringá, v. 31 n. 3, p. 37-52, set./dez. 2012.

; FADEL, M. O.; TAKAMATSU, R. T. Em busca da essência de um bom professor: uma análise sobre a percepção discente dos cursos de pós-graduação na área de negócios. ReCont: registro contábil, Alagoas, v. 3, n. 3, p. 12-31, set./dez. 2012.

PIERRE, K. S. et al. The role of accounting education research in our discipline: an editorial. Issues in Accounting Education, Sarasota, v. 24, n. 2, p. 123-130, May 2009.

PIMENTA, S. G.; ANASTASIOU, L. G. Docência no ensino superior. São Paulo: Cortez, 2002.
RUFF, M.; THIBODEAU, J. C.; BERDARD, J. C. A profession's response to a looming shortage: closing the gap in the supply. Journal of Accountancy, New York, v. 207, n. 3, p. 3640, Mar. 2009.

SCHÖN, D. A. Educando o profissional reflexivo: um novo design para o ensino e a aprendizagem. Porto Alegre: ArtMed, 2000.

SEVERINO, A. J. Ensino e pesquisa na docência universitária: caminhos para a integração. Cadernos Pedagogia Universitária, São Paulo, n. 3, abr. 2009.

SHULMAN, L. S. Signature pedagogies in the professions. Dædalus, Cambridge, v. 34, n. 3, p. 52-59, Summer 2005.

. Those who understand: knowledge growth in teaching. Educational Researcher, Washington, D.C., v. 15, n. 2, p. 4-14, Feb. 1986.

SLOMSKI, V. G. Saberes que fundamentam a prática pedagógica dos professores de ciências contábeis. Revista Brasileira de Contabilidade, Brasília, n. 178-180, p. 119-140, jul/dez, 2009.

TRAPNELL, J. E. et al. The accounting doctoral shortage: time for a new model. Issues in Accounting Education, Sarasota, v. 24, n. 4, p. 427-432, Nov. 2009.

VASCONCELOS, M. L. M. C. A formação do professor do ensino superior. 3. ed. São Paulo: Xamã, 2009.

VERHINE, R. E.; DANTAS, L. M. V.; SOARES, J. F. Do provão ao ENADE: uma análise comparativa dos exames nacionais utilizados no ensino superior brasileiro. Ensaio: avaliação e políticas públicas em educação, Rio de Janeiro, v. 14 , n. 52, p. 291-310, jul./set. 2006.

VOLPATO, G. Marcas de profissionais liberais que se tornaram professores-referência. Revista Brasileira de Estudos Pedagógicos, Brasília, v. 90, n. 225, p. 333-351, maio/ago. 2009. 